\title{
HUBUNGAN ANTARA KECERDASAN EMOSIONAL DENGAN KECENDERUNGAN BURNOUT PADA KARYAWAN BAGIAN PEMASARAN
}

\author{
Madeline S. Widjaja ${ }^{l}$, \\ Kartika S. Sitorus, \\ Karel K. Himawan \\ Fakultas Psikologi \\ Universitas Pelita Harapan \\ Jl. MH. Thamrin Boulevard, Lippo Karawaci, \\ Tangerang 15811, Indonesia \\ ${ }^{1}$ e-mail: madeline_widjaja@hotmail.com
}

\begin{abstract}
Working is a stage in the path of life each human will pass. However, during employment, a person may experience pressure and if the pressure persists, the situation may tend to lead to burnout. Burnout is a syndrome of emotional fatigue due to excessive working demands. The effect of burnout is not only experienced physically, but also psychologically. Burnout is caused by numerous factors, both external and internal. Internal factor includes emotional intelligence. The purpose of this study was to observe and identify the correlation between emotional intelligence and burnout tendency of employees in the marketing department. This study adopted 104 samples and data are collected through questionnaires. Based on the statistical tests conducted, significant correlation exists between emotional intelligence and burnout tendency of employees in the marketing department. The correlation was negative, implying that the higher the emotional intelligence employees have, the lower the burnout tendency they may have, and vice versa.
\end{abstract}

Keywords: emotional intelligence; burnout; marketing employees

Abstrak - Bekerja merupakan sebuah tahap yang pasti akan dilalui oleh setiap manusia. Namun, dalam bekerja seseorang dapat mengalami tekanan dan apabila berkelanjutan maka dapat berkembang menjadi kecenderungan burnout. Burnout merupakan suatu sindrom kelelahan emosional akibat adanya tekanan karena tuntutan pekerjaan yang terlalu banyak. Burnout dipengaruhi oleh berbagai faktor, baik faktor eksternal maupun internal. Faktor internal yang dimaksud dalam hal ini adalah kecerdasan emosional. Tujuan dari penelitian ini adalah untuk mengetahui ada atau tidaknya hubungan antara kecerdasan emosional dengan burnout pada karyawan bagian pemasaran. Penelitian ini menggunakan sampel sebanyak 104, dan menggunakan instrumen kuesioner. Berdasarkan uji statistik, didapatkan hasil bahwa terdapat hubungan yang signifikan antara kecerdasan emosional dengan kecenderungan burnout pada karyawan bagian pemasaran. Hubungan yang ada bersifat negatif, artinya semakin tinggi tingkat kecerdasan emosional seseorang, maka tingkat kecenderungan burnout semakin rendah, dan begitu pula sebaliknya. 
Kata kunci: kecerdasan emosional; burnout; pemasaran

\section{PENDAHULUAN}

Sebagian besar waktu dalam hidup manusia dihabiskan untuk bekerja (Khanifar, Maleki, Nazhari, \& Emami, 2012). Dengan demikian, bekerja menjadi suatu tahap yang penting dalam hidup manusia. Bekerja dapat mempengaruhi diri manusia baik fisik maupun psikisnya. Khanifar et al. (2012) juga mengatakan bahwa bekerja merupakan upaya untuk memenuhi kebutuhan dalam hidup manusia. Setiap orang dalam posisi dan situasi apapun akan mengalami tekanan dalam bekerja. Hal ini merupakan kenyataan yang tidak dapat dihindari dan menjadi sorotan dalam dunia organisasi. Tekanan yang didapat dari pekerjaan dapat mengarahkan seseorang pada kelelahan bekerja. Kelelahan bekerja yang dimaksud dalam hal ini adalah kecenderungan burnout. Hal tersebut juga diperkuat oleh pendapat dari Muchinsky (2000), bahwa kecenderungan burnout dapat dialami oleh karyawan yang berasal dari berbagai bidang bila memang mendapat tekanan yang berlebihan dan menguras energi sehingga mengalami frustrasi yang berkelanjutan. Meskipun kecenderungan burnout biasanya dialami oleh karyawan dalam bidang human service seperti perawat, guru, konselor, dan petugas kepolisian, kecenderungan burnout juga dapat dialami oleh karyawan di luar bidang human service seperti karyawan di bidang pemasaran, bila memang mengalami tekanan sehingga mengurangi energi dalam bekerja (Muchinsky, 2000).

Burnout merupakan istilah yang pertama kali diungkapkan oleh Freudenberger (dalam Maslach, 1993) untuk menggambarkan respon negatif yang dihasilkan oleh tekanan dalam pekerjaan dan menimbulkan sindrom stres psikologis. Menurut Maslach (1993), burnout memiliki tiga dimensi, yaitu emotional exhaustion, depersonalization (cynicism), dan reduced personal accomplishment. Emotional exhaustion, atau kelelahan emosional, berarti keadaan dimana seseorang kehilangan kontrol akan emosinya. Depersonalization (cynicism), atau depersonalisasi, terjadi ketika seseorang membatasi dirinya dengan lingkungan sekitar, sehingga dalam berinteraksi sikap yang ditampilkan cenderung bersifat negatif agar dirinya terhindar dari kekecewaan. Sedangkan reduced personal accomplishment, atau rendahnya penghargaan terhadap diri sendiri, adalah kecenderungan seseorang untuk memberikan penilaian negatif akan hasil kerjanya. Ketiga 
dimensi tersebut saling berinteraksi hingga pada akhirnya memunculkan kecenderungan burnout dalam diri seseorang.

Berbagai penelitian telah dilakukan untuk meneliti faktor-faktor yang mempengaruhi kecenderungan burnout. Peneliti melihat sebagian besar penelitian yang dilakukan adalah penelitian seputar faktor-faktor fisik atau eksternal. Faktor eksternal yang dimaksud ini adalah seperti struktur dan iklim organisasi.

Berdasarkan eksplorasi peneliti, terdapat pula beberapa penelitian yang mengkaitkan faktor internal dengan kecenderungan burnout, seperti penelitian yang dilakukan oleh Tawale, Budi, dan Nurcholis (2011) yang meneliti mengenai hubungan motivasi bekerja dengan kecenderungan burnout; Khanifar et al. (2012) yang meneliti mengenai hubungan kecerdasan emosional dengan kecenderungan burnout; dan Widiastuti dan Astuti (2008) yang meneliti mengenai hubungan kepribadian hardiness dengan kecenderungan burnout. Namun, penelitian-penelitian tersebut dilakukan pada subjek dalam bidang human service. Oleh karena itu, penelitian pada subjek dalam bidang non human service menjadi penting untuk dilakukan, salah satunya pada subjek karyawan di bidang pemasaran.

Setiap karyawan dapat mengalami tekanan dalam bekerja yang disebabkan oleh berbagai faktor eksternal, tetapi tidak setiap karyawan akan mengalami kecenderungan burnout. Hal ini terjadi karena setiap individu memiliki karakteristik pribadi yang berbeda-beda, sehingga kemampuan yang dimiliki seseorang untuk menanggapi tekanan juga berbeda-beda (Corrigan, Holmes, \& Luchins, 1995). Oleh karena itu, penelitian mengenai faktor yang berpengaruh terhadap kecenderungan burnout juga perlu dilakukan pada faktor internal yaitu faktor dalam diri seseorang. Faktor internal ini dapat menjadi salah satu faktor penting yang dapat menjadi prediktor stres dalam bekerja.

Salah satu kemampuan tersebut adalah kecerdasan emosional yang dimiliki setiap individu. Dengan adanya kecerdasan emosional, seseorang memiliki regulasi diri untuk dapat mengontrol dirinya agar tidak terpengaruh beban kerja secara berlebihan yang mungkin dapat berkembang menjadi kecenderungan burnout. Bagaimanapun, kondisi burnout muncul bukan hanya dipengaruhi oleh kondisi organisasi, namun merupakan hasil interaksi antara kondisi organisasi dengan karakteristik individu, misalnya kondisi emosi (Ema, 2004).

Goleman (2005) mengutarakan definisi kecerdasan emosional sebagai kompetensi yang dimiliki manusia untuk mengelola diri dan hubungan dengan orang lain, membangun kerja sama yang efektif, memimpin orang lain, dan memperkirakan masa depan, dimana semua hal tersebut berdampak positif terhadap performa dalam bekerja. 
Kecerdasan emosional memiliki beberapa dimensi yaitu self awareness, self regulatory, self motivating, empathy, dan social skills (Goleman, 2005). Self awareness merupakan kemampuan untuk memahami dan mengenali emosi ketika emosi tersebut terjadi. Self regulatory merupakan kemampuan untuk menangani emosi agar dapat terungkap dengan tepat. Self motivating merupakan kemampuan untuk menerapkan optimisme dalam diri. Empathy merupakan kemampuan untuk menempatkan diri dalam posisi orang lain serta memahami perasaan orang lain. Social skills merupakan kemampuan dalam membina hubungan dengan orang lain.

Berdasarkan penelitian yang dilakukan oleh Akbar (2013), dapat terlihat bahwa seseorang dengan kecerdasan emosional yang baik seharusnya dapat memahami berbagai emosi yang dirasakannya, termasuk tekanan dari pekerjaan, serta dapat mengendalikannya. Goleman (2005) mengutarakan bahwa kecerdasan emosional menimbulkan berbagai dampak positif dalam diri seorang karyawan yang membutuhkan berbagai kemampuan untuk menangani tekanan bekerja.

Dari berbagai paparan di atas, dapat terlihat bahwa kecerdasan emosional menimbulkan berbagai dampak positif dalam diri seseorang, seperti kemampuan untuk meregulasi emosi sehingga dapat merespon tekanan dengan positif dan terhindar dari kecenderungan burnout. Hal ini tentu relevan juga bagi karyawan, khususnya mereka yang terlibat dalam bidang pemasaran dimana tuntutan pekerjaannya cukup banyak melibatkan aspek emosional.

Karyawan yang bekerja dalam bidang pemasaran merupakan tenaga penjualan yang menjadi penghubung utama antara suatu perusahaan dengan pelanggan (Bergen, Dutta, \& Walker, 1992). Sebagai karyawan dalam bidang pemasaran, para karyawan dituntut agar dapat menghubungkan perusahaan dengan pelanggan. Dalam berinteraksi dengan berbagai pelanggan yang beragam, sisi emosional seseorang dilibatkan. Seorang karyawan pemasaran perlu mengutamakan efisiensi dan ramah tamah dalam bekerja, sehingga hal lainnya seperti masalah pribadi, keluhan, dan emosi yang dirasakan sebenarnya perlu dikesampingkan (Lupiyoadi, 2001). Dengan demikian, karyawan pemasaran perlu memiliki keseimbangan antara emosi yang ditunjukkan dengan emosi lainnya yang sebenarnya dirasakan, agar tidak mengalami tekanan dalam bekerja.

Seorang karyawan di bidang pemasaran harus menjaga hubungan baik dengan pelanggan agar hubungan yang terjalin dapat bersifat jangka panjang, sehingga perlu menampilkan sikap dan emosi sesuai dengan tuntutan pekerjaannya setiap saat (Storbacka, Ryals, Iain, \& Nenonen, 2009). Hal ini disebut dengan emotional labor, dimana setiap karyawan perlu melakukan usaha untuk mengekspresikan emosi yang pantas kepada atasan dan pelanggan sesuai dengan kondisi pekerjaannya masing-masing (Hoschild, dalam Grandey, 2000). Oleh karena itu, seseorang perlu meregulasikan serta mengatur emosi dalam diri, sehingga dapat mengekspresikan emosi yang tepat 
sesuai dengan tuntutan kerja. Menurut Grandey (2000), apabila karyawan tidak dapat meregulasikan emosinya, maka ia akan mengalami emotional dissonance yang disebabkan oleh ketidakseimbangan antara emosi yang ditampilkan dan emosi yang sebenarnya dirasakan. Berdasarkan pendapat Morris dan Feldman (dalam Bakker \& Heuven, 2006), emotional dissonance dapat memprediksi kelelahan emosi yang berkepanjangan dan mengarah pada kelelahan kerja atau burnout.

Oleh karena itu, berdasarkan fenomena-fenomena yang telah dipaparkan di atas, terlihat pentingnya faktor internal, dalam hal ini merupakan kecerdasan emosional bagi karyawan, khususnya bagi mereka yang bekerja di bagian pemasaran. Maka peneliti tertarik untuk meneliti tentang hubungan antara kecerdasan emosional dan kecenderungan burnout pada karyawan bagian pemasaran.

\section{METODE}

\section{Partisipan}

Partisipan dalam penelitian ini adalah karyawan bagian pemasaran yang bekerja di beberapa perusahaan di Jakarta dan memenuhi kriteria penelitian. Metode pemilihan partisipan yang digunakan dalam penelitian ini adalah non probability sampling, yaitu purposive sampling. Purposive sampling adalah teknik penentuan sampel dengan pertimbangan dan tujuan tertentu (Sugiyono, 2010). Kriteria sampel dalam penelitian ini adalah: (1) Karyawan atau karyawati di bagian pemasaran, (2) Bekerja purna waktu, (3) Bekerja di perusahaan-perusahaan yang berlokasi di Jakarta, (4) Berusia 15 - 64 tahun, dan (5) Lama bekerja minimal satu tahun.

\section{Desain}

Desain penelitian yang dilakukan dalam penelitian ini adalah menggunakan pendekatan kuantitatif. Jenis penelitian kuantitatif yang digunakan dalam penelitian ini adalah penelitian korelasional. Penelitian korelasional merupakan penelitian yang dirancang untuk menentukan tingkat hubungan variabel-variabel yang berbeda dalam suatu populasi (Sevilla, Ochave, Punsalan, Regala, \& Uriarte, 1993). Melalui penelitian ini hasil yang diperoleh merupakan apakah terdapat hubungan yang signifikan atau tidak antara kedua variabel. 


\section{Prosedur}

Tahap persiapan dalam penelitian ini dimulai dengan mencari masalah yang menarik untuk diteliti. Pencarian masalah penelitian ini dilakukan dengan mencari berbagai informasi suatu fenomena melalui penelitian-penelitian sebelumnya, buku, jurnal, artikel, dan berbagai teori-teori yang memiliki kaitan dengan masalah yang ditentukan. Masalah penelitian ini lalu dikembangkan dengan menyusun latar belakang dan juga tinjauan kepustakaan seputar topik penelitian. Lalu, dilakukan perancangan metode penelitian dan pemilihan instrumen penelitian yang sesuai untuk digunakan dalam penelitian ini. Langkah berikutnya adalah meminta permohonan izin kepada penyusun kuesioner kecerdasan emosional yaitu Lanawati (1999). Permohonan izin juga disampaikan kepada perusahaan-perusahaan yang dituju untuk meminta kesediaan berpartisipasi dalam penelitian ini.

Pada tahap pelaksanaan, dilakukan try out alat ukur yang telah dipilih sebelumnya dan telah diadaptasi oleh peneliti terlebih dahulu. Dari hasil try out tersebut, peneliti melakukan uji validitas dan reliabilitas dari alat ukur. Selanjutnya, setelah memastikan bahwa alat ukur yang digunakan valid dan reliabel, maka peneliti menyebarkan alat ukur kepada sampel yang sesuai dengan kriteria yang telah ditentukan.

Pada tahap pelaporan, peneliti akan melakukan pengolahan serta analisis data yang telah diperoleh melalui alat ukur yang telah disebarkan. Pengolahan data dilakukan dengan menggunakan software SPSS 21.0. Selanjutnya, peneliti menyusun pembahasan hasil pengolahan dan analisis data hingga dapat membentuk kesimpulan dan saran. Tahap terakhir adalah melaporkan hasil dari penelitian ini.

Dalam penelitian ini, metode pengambilan data yang digunakan adalah dengan menggunakan angket atau kuesioner. Angket atau kuesioner adalah teknik pengumpulan data yang efisien dimana responden diminta untuk mengisi pertanyaan atau pernyataan yang diberikan kepada responden secara langsung atau dikirim melalui pos ataupun internet (Sugiyono, 2010). Pada kuesioner yang akan dibagikan terdapat dua bagian, yaitu bagian data demografis dan bagian alat ukur.

Alat ukur yang digunakan untuk mengukur tingkat kecenderungan burnout adalah Maslach Burnout Inventory (MBI) yang disusun oleh Maslach dan Jackson (1986). Alat ukur ini berisi 16 items yang terdiri dari 5 items dari dimensi emotional exhaustion, 5 items dari dimensi cynicism, dan 6 items dari dimensi reduced professional efficacy. Dengan menggunakan Alpha Cronbach, reliabilitas alat ukur ini adalah .71 - .93, sedangkan nilai validitas diskriminan teruji dengan hasil 
.337 - .836 (Poghosyan, Aiken, \& Sloane, 2009). Pada penelitian ini, nilai reliabilitas Alpha Cronbach yang diperoleh adalah .844 .

Alat ukur yang digunakan untuk mengukur tingkat kecerdasan emosional adalah alat ukur yang diadaptasi dari kuesioner Emotional Intelligence Quotient Inventory atau Inventori Kecerdasan Emosional yang dikembangkan oleh Lanawati (1999). Alat ukur ini berisi 92 items yang terdiri dari 12 items dari dimensi self awareness, 25 items dari dimensi self regulatory, 14 items dari dimensi self motivating, 17 items dari dimensi empathy, 12 items dari dimensi social skills, dan 12 items konsistensi. Nilai reliabilitas alpha alat ukur ini ialah .93 (Marina \& Sarwono, 2007). Dalam penelitian ini, nilai reliabilitas yang diperoleh ialah .899, dengan masing-masing dimensi memiliki nilai alpha antara .606 hingga .868 .

\section{Teknik Analisis Data}

Untuk menguji hipotesis, digunakan teknik korelasi Pearson untuk mengetahui ada atau tidaknya korelasi antara kecerdasan emosional dengan kecenderungan burnout. Sebelum menguji hipotesis, akan dilakukan uji normalitas terlebih dahulu dengan menggunakan uji KolmogorovSmirnov.

\section{ANALISIS DAN HASIL}

Uji normalitas data dilakukan menggunakan uji Kolmogorov-Smirnov. Data yang memiliki distribusi normal adalah data yang memiliki nilai signifikansi $p>0.05$ (Santoso, 2010). Setelah diuji, variabel kecenderungan burnout $(p=0.200)$ dan kecerdasan emosional $(p=0.200)$ menunjukkan data yang berdistribusi normal.

Dalam penelitian ini, uji hipotesis dibuktikan dengan uji korelasi di antara variabel. Karena data berdistribusi normal, maka uji korelasi dilakukan dengan Pearson Product Moment Correlation. Hasil uji statistik menunjukkan bahwa terdapat korelasi yang signifikan di antara kecerdasan emosional dengan kecenderungan burnout $(r=-0.409 ; p=0.000)$. Hubungan yang ada adalah hubungan yang negatif. Dimana yang dimaksud dengan hubungan negatif adalah semakin tinggi kecenderungan burnout, maka semakin rendah tingkat kecerdasan emosionalnya, begitu pula sebaliknya.

Selain itu, untuk data analisis tambahan, dilakukan pula analisis uji korelasi kecenderungan burnout terhadap masing-masing dimensi kecerdasan emosional. 
Tabel 1.

Tabel Analisis Burnout dengan Dimensi Kecerdasan Emosional

\begin{tabular}{|c|c|c|c|c|c|}
\hline & $\begin{array}{l}\text { Self } \\
\text { Awareness }\end{array}$ & Self Regulatory & $\begin{array}{l}\text { Self } \\
\text { Motivating }\end{array}$ & Empathy & Social Skills \\
\hline Burnout & $-0.271 * *$ & $-0.376^{* *}$ & $-0.246^{*}$ & -0.116 & $-0.313 * *$ \\
\hline
\end{tabular}

Keterangan: *: signifikan pada tingkat .05; **: signifikan pada tingkat .001

Tabel di atas menunjukkan bahwa masing-masing dimensi kecerdasan emosional yaitu self awareness, self regulatory, self motivating, empathy, dan social skills memiliki hubungan negatif yang signifikan dengan variabel kecenderungan burnout. Dimensi yang memiliki hubungan negatif yang paling kuat dengan kecenderungan burnout adalah dimensi self regulatory $(r=-0.376 ; p<$ 0.05). Selanjutnya, dilakukan pula analisis uji korelasi kecerdasan emosional terhadap masingmasing dimensi kecenderungan burnout.

Tabel 2.

Tabel Analisis Kecerdasan Emosional dengan Dimensi Burnout

\begin{tabular}{llll}
\hline & Emotional Exhaustion & Cynicism & Reduced Professional Efficacy \\
\hline Kecerdasan & $-0.335^{* *}$ & $-0.200^{*}$ & $-0.344^{* *}$ \\
Emosional & & & \\
\hline
\end{tabular}

Keterangan: *: signifikan pada tingkat .05; **: signifikan pada tingkat .001

Tabel di atas menunjukkan bahwa masing-masing dimensi kecenderungan burnout, yaitu emotional exhaustion, cynicism, dan reduced professional efficacy memiliki hubungan yang signifikan dengan variabel kecerdasan emosional. Dimensi yang memiliki hubungan yang paling kuat dengan kecerdasan emosional adalah dimensi reduced professional efficacy $(r=-0.344 ; p<$ $0.05)$.

Berikutnya, dilakukan juga analisis data berdasarkan data demografis. Analisis data ini dilakukan untuk mengetahui ada atau tidaknya perbedaan data demografis terhadap variabel kecenderungan burnout dan kecerdasan emosional. Data demografis yang diuji antara lain adalah usia, jenis kelamin, status perkawinan, pendidikan terakhir, posisi atau jabatan, jenis produk yang dipasarkan, lama bekerja, dan riwayat bekerja sebelumnya. Untuk data jenis kelamin dan status perkawinan diuji menggunakan independent sample t-test, sedangkan data pendidikan terakhir, 
posisi atau jabatan, jenis produk yang dipasarkan, dan riwayat bekerja sebelumnya diuji menggunakan ANOVA. Untuk data usia dan lama bekerja menggunakan uji korelasi.

Hasil analisis menunjukkan bahwa terdapat beberapa perbedaan yang signifikan berdasarkan data demografis pada kecenderungan burnout yaitu berdasarkan pendidikan terakhir dan posisi atau jabatan. Berdasarkan data pendidikan terakhir $(F=3.101 ; p=0.049)$ terdapat perbedaan yang signifikan antara kelompok D3 dengan S1, dimana kelompok S1 memiliki mean tertinggi $(M=$ 48.178) dan D3 memiliki mean terendah $(M=39.607)$. Sedangkan pada data posisi atau jabatan $(F$ $=3.401 ; p=0.037)$ terdapat perbedaan yang signifikan antara kelompok supervisor dengan manajer atau direktur, dimana kelompok supervisor memiliki mean tertinggi $(M=54.666)$ dan kelompok manajer atau direktur memiliki mean terendah $(M=39.555)$.

Beberapa hasil analisis data tambahan pada variabel burnout maupun kecerdasan emosi ditunjukkan dalam Tabel 3 berikut.

Tabel 3.

Hasil Analisis Data Tambahan

\begin{tabular}{|c|c|}
\hline Variabel & Hasil \\
\hline $\begin{array}{l}\text { Kecenderungan burnout dan pendidikan } \\
\text { terakhir. }\end{array}$ & $\begin{array}{l}\text { Kelompok D3 berbeda signifikan dengan } \\
\text { kelompok S1 }(p=0.044) \text {. }\end{array}$ \\
\hline $\begin{array}{l}\text { Kecenderungan burnout dan jabatan } \\
\text { dalam pekerjaan. }\end{array}$ & $\begin{array}{l}\text { Kelompok supervisor berbeda signifikan } \\
\text { dengan kelompok manajer dan direktur }(p= \\
0.043) \text {. }\end{array}$ \\
\hline $\begin{array}{l}\text { Kecenderungan burnout dan jenis } \\
\text { kelamin. }\end{array}$ & $\begin{array}{l}\text { Tidak ditemukan perbedaan yang signifikan }(t \\
=0.633 ; p=0.528) .\end{array}$ \\
\hline $\begin{array}{l}\text { Kecenderungan burnout dan jenis produk } \\
\text { yang dipasarkan. }\end{array}$ & $\begin{array}{l}\text { Tidak ditemukan perbedaan yang signifikan } \\
(F=1.665 ; p=0.164) \text {. }\end{array}$ \\
\hline $\begin{array}{l}\text { Kecenderungan burnout pada partisipan } \\
\text { yang memiliki riwayat kerja sebelumnya } \\
\text { dengan yang tidak. }\end{array}$ & $\begin{array}{l}\text { Tidak ditemukan perbedaan yang signifikan } \\
(F=0.005 ; p=0.943) \text {. }\end{array}$ \\
\hline $\begin{array}{l}\text { kecerdasan emosional dengan jenis } \\
\text { kelamin. }\end{array}$ & $\begin{array}{l}\text { Tidak ditemukan perbedaan yang signifikan }(t \\
=-0.148 ; p=0.883) .\end{array}$ \\
\hline $\begin{array}{l}\text { Kecerdasan emosional dengan status } \\
\text { pernikahan. }\end{array}$ & $\begin{array}{l}\text { Tidak ditemukan perbedaan yang signifikan }(t \\
=0.332 ; p=0.741) .\end{array}$ \\
\hline $\begin{array}{l}\text { Kecerdasan emosional dengan pendidikan } \\
\text { terakhir, jabatan, produk yang dipasarkan, } \\
\text { dan riwayat bekerja sebelumnya. }\end{array}$ & $\begin{array}{l}\text { Tidak ditemukan perbedaan yang signifikan } \\
\text { antara kecerdasan emosional dengan } \\
\text { pendidikan terakhir }(F=0.813 ; p=0.446) \text {, } \\
\text { posisi atau jabatan }(F=0.457 ; p=0.634 ; p> \\
0.05) \text {, produk yang dipasarkan }(F=1.024 ; p= \\
0.399) \text {, dan riwayat bekerja sebelumnya }(F= \\
1.147 ; p=0.287) \text {. }\end{array}$ \\
\hline $\begin{array}{l}\text { Usia dengan kecenderungan burnout dan } \\
\text { kecerdasan emosional. }\end{array}$ & $\begin{array}{l}\text { Tidak ada korelasi yang signifikan antara usia } \\
\text { dengan kecenderungan burnout }(r=0.010 ; p \\
=0.919) \text { dan dengan kecerdasan emosional } \\
\text { partisipan }(r=0.034 ; p=0.735) \text {. }\end{array}$ \\
\hline Lama bekerja dengan kecenderungan & Tidak ada korelasi yang signifikan antara \\
\hline
\end{tabular}




\section{burnout dan kecerdasan emosional. lama bekerja dengan kecenderungan burnout $(r=-0.052 ; p=0.597)$ dan dengan kecerdasan emosional $(r=0.147 ; p=0.138)$.}

\section{DISKUSI}

Tujuan dari penelitian ini adalah untuk mengetahui ada atau tidaknya hubungan yang signifikan antara kecerdasan emosional dengan kecenderungan burnout pada karyawan bagian pemasaran. Berdasarkan hasil analisis korelasi didapatkan bahwa hipotesis $\left(\mathrm{H}_{1}\right)$ dalam penelitian ini diterima, artinya terdapat hubungan yang signifikan antara kecerdasan emosional dengan kecenderungan burnout pada karyawan bagian pemasaran $(r=-0.409 ; p<0.05)$. Hubungan yang ada bersifat hubungan negatif, maksudnya adalah semakin tinggi tingkat kecerdasan emosional seseorang, maka semakin rendah tingkat kecenderungan burnout seseorang, begitu pula sebaliknya. Hasil penelitian ini sejalan dengan penelitian sebelumnya yang juga meneliti mengenai hubungan antara kecerdasan emosional dengan kecenderungan burnout (Khanifar et al., 2012; Nikolaou \& Tsaousis, 2002).

Dalam penelitian ini, hal tersebut secara khusus dilihat pada karyawan bagian pemasaran yang memiliki kewajiban utama untuk menjadi penghubung utama antara pelanggan dan perusahaan. Sebagai penghubung utama, karyawan bagian pemasaran perlu menjadi representasi yang memberikan informasi kepada dua belah pihak, baik pelanggan dan juga membawa informasi mengenai pelanggan yang berguna bagi perusahaan. Sebagai penghubung utama, karyawan bagian pemasaran perlu menampilkan emosi dan tingkah laku yang sesuai dengan pekerjaannya, agar terjalin hubungan yang baik antar kedua belah pihak. Tindakan untuk menampilkan emosi yang sesuai dengan tuntutan pekerjaan disebut dengan emotional labor (Hoschild, dalam Grandey, 2000).

Hal tersebut juga diperkuat oleh pendapat dari Storbacka et al. (2009) yang mengatakan bahwa seorang karyawan bagian pemasaran perlu mempraktekkan emosi-emosi tertentu yang sesuai dengan tuntutan pekerjaannya untuk menjaga hubungan baik dengan pelanggan. Emosi-emosi yang sesuai dengan pekerjaannya merupakan emosi positif yang dapat menggambarkan antusiasme seseorang untuk menarik perhatian dari pelanggannya. Emosi-emosi positif yang dimaksud antara lain mengacu pada emosi-emosi seperti keriangan, kedamaian, kebahagiaan, dan kepuasan (Baumgardner \& Crothers, 2010). Apabila seseorang tidak dapat melaksanakan emotional labor dengan baik, maka seseorang dapat mengalami emotional dissonance yang merupakan adanya ketidakseimbangan dalam diri seseorang antara emosi yang dirasakan sebenarnya dengan emosi yang ditampilkan. Morris dan Feldman (dalam Bakker \& Heuven, 2006) mengatakan bahwa 
emotional dissonance dapat memprediksi kelelahan emosi yang berkepanjangan dan mengarah pada kelelahan kerja atau burnout.

Oleh karena itu, seseorang perlu memiliki kemampuan-kemampuan untuk membantu agar dapat melaksanakan emotional labor dengan mudah. Kemampuan yang dimaksud dalam hal ini merupakan kemampuan yang tercakup dalam kecerdasan emosional. Kecerdasan emosional meliputi beberapa dimensi yang menunjang pelaksanaan emotional labor, seperti dimensi self regulatory yang merupakan dimensi yang memiliki hubungan paling kuat dengan kecenderungan burnout ( $r=-0.376, p<0.05$ ). Self regulatory berperan sebagai pengontrol agar respon emosi yang diekspresikan seseorang menjadi pantas dan sesuai dengan emotional labor. Jadi, self regulatory merupakan pengontrol diri yang bertujuan untuk menjaga keseimbangan emosi.

Namun, sebelum seseorang dapat meregulasi emosinya, maka terlebih dahulu ia perlu memahami emosi yang dirasakan. Kemampuan memahami emosi ini merupakan kemampuan dalam dimensi self awareness $(r=-0.271 ; p<0.05)$ yang juga memiliki hubungan yang signifikan dengan kecenderungan burnout. Dimensi self awareness ini membantu seorang karyawan untuk dapat memahami perasaannya. Pemahaman emosi ini membuat seseorang menjadi waspada akan suasana hatinya agar tidak dikuasai oleh aliran emosi (Mayer, dalam Goleman, 2005).

Dalam mempraktikkan emotional labor, diperlukan juga kemampuan untuk memiliki optimisme dalam hidup. Kemampuan ini merupakan kemampuan dari dimensi self motivating $(r=$ 0.246; $p<0.05)$ yang juga memiliki hubungan yang signifikan dengan kecenderungan burnout. Kemampuan untuk memiliki optimisme ini menunjang pelaksanaan emotional labor yang mengharuskan seseorang menampilkan emosi-emosi yang positif. Dengan memiliki optimisme dalam diri, maka seseorang akan lebih mudah mengekspresikan hal-hal yang optimis pula.

Dimensi social skills $(r=-0.313 ; p<0.05)$ yang juga memiliki hubungan signifikan dengan kecenderungan burnout merupakan kemampuan dalam membina hubungan dengan orang lain, khususnya dalam berkomunikasi dengan orang lain (Goleman, 2005). Ketika seseorang melakukan emotional labor, maka orang tersebut secara tidak langsung bertujuan agar terbentuk hubungan yang baik dengan pelanggan dan juga perusahaan. Dengan adanya social skills, seorang karyawan memiliki kemampuan untuk berinteraksi dan berkomunikasi dengan orang lain dan sesuai dengan emotional labor.

Menarik dalam penelitian ini adalah terdapat pula kemampuan dalam kecerdasan emosional yang tidak memiliki hubungan yang signifikan dengan kecenderungan burnout, yaitu dimensi empathy $(r=-0.116 ; p<0.05)$. Berbeda dengan dimensi-dimensi sebelumnya, empathy memiliki fokus pada orang lain, sedangkan dimensi lain memiliki fokus terhadap diri sendiri. Empathy 
merupakan kemampuan untuk menempatkan diri dalam posisi orang lain serta memahami perasaan orang lain (Goleman, 2005). Dengan kemampuan ini, seseorang lebih dapat memahami sudut pandang orang lain termasuk pelanggan dan perusahaan. Di sisi lain, menurut Cordes dan Dougherty (1993), seseorang yang mengalami burnout akan membatasi dirinya dari lingkungan sekitar dan cenderung bersikap acuh tak acuh terhadap orang lain. Dengan kata lain, ketika seseorang mengalami burnout, maka orang tersebut menjadi fokus pada dirinya sendiri dan targettarget yang perlu dicapai. Hal ini bertentangan dengan empathy yang memiliki fokus untuk memahami perasaan orang lain. Mungkin karena hal yang bertentangan ini menyebabkan tidak adanya hubungan antara empathy dengan kecenderungan burnout. Ketika seseorang bekerja, ia membutuhkan regulasi emosi untuk membatasi hubungan yang dimiliki dengan pelanggan agar tidak terjadi emotional exhaustion (Maslach, Jackson, \& Leiter, 1996). Hal ini menunjukkan bahwa ketika melakukan emotional labor, seorang karyawan hanya berusaha untuk memahami orang lain hanya sebatas dalam konteks pekerjaan saja, tidak benar-benar memahami orang lain secara mendalam. Oleh karena itu, ketika seseorang melakukan emotional labor, berarti ia tidak melakukan empathy yang sebenarnya secara mendalam.

Sebaliknya, dimensi-dimensi dari burnout juga memiliki hubungan dengan kecerdasan emosional. Hubungan yang paling kuat ditemukan pada dimensi reduced professional efficacy $(r=-$ 0.344; $p<0.05)$. Reduced professional efficacy merupakan ekspektasi dan pandangan yang negatif terhadap efikasi diri saat bekerja (Campbell \& Rothman, 2005). Pandangan yang negatif menekan segala kemampuan yang dimiliki seseorang. Oleh karena itu, reduced professional efficacy memiliki hubungan negatif yang kuat dengan kecerdasan emosional.

Emotional exhaustion $(r=-0.335 ; p<0.05)$ juga merupakan dimensi yang memiliki hubungan negatif yang kuat dengan kecerdasan emosional. Sebagai dimensi utama dari burnout, emotional exhaustion terjadi apabila seseorang kehilangan kontrol akan emosinya sehingga energinya terkuras akibat keterlibatan emosi dengan intensitas yang tinggi dalam melaksanakan pekerjaan. Hal ini dapat terjadi apabila seseorang tidak memiliki kemampuan regulasi antara emosi yang sebenarnya dirasakan dengan emosi yang perlu ditampilkan, sehingga kehilangan kontrol keseimbangan.

Untuk memperkaya hasil penelitian, peneliti melakukan analisis terhadap data demografis subjek. Hasil yang ditemukan adalah adanya perbedaan yang signifikan berdasarkan pendidikan terakhir $(F=3.101 ; p=0.049 ; p<0.05)$ dan berdasarkan posisi atau jabatan $(F=3.401 ; p=0.037$; $p<0.05)$ dalam hal kecenderungan burnout. Namun, oleh karena terdapat keterbatasan sumber 
kajian mengenai hal ini yang dimiliki oleh peneliti, maka hal ini tidak dapat dibahas lebih lanjut lagi.

Menurut Storbacka et al. (2009), setiap karyawan yang berada pada bidang pemasaran tidak hanya menjual, tetapi juga perlu memperhatikan produktivitas pelanggan. Hal ini menunjukkan bahwa setiap karyawan bagian pemasaran memiliki tuntutan dan peran yang sama. Hal tersebut juga sesuai dengan hasil penelitian ini, dimana sebagian besar data demografis seperti usia, jenis kelamin, dan sebagainya, tidak memiliki perbedaan signifikan terhadap kecerdasan emosional dan kecenderungan burnout.

\section{SIMPULAN DAN SARAN}

\section{Simpulan}

Penelitian ini bertujuan untuk mengukur hubungan yang signifikan antara kecerdasan emosional dan kecenderungan burnout pada karyawan bidang pemasaran. Data penelitian diperoleh berdasarkan hasil penyebaran kuesioner pada 104 subjek karyawan bagian pemasaran.

Hasil penelitian menunjukkan bahwa ada hubungan yang signifikan antara kecerdasan emosional dengan kecenderungan burnout pada karyawan bagian pemasaran $(r=-0.409 ; p<0.05)$, dimana apabila seseorang yang memiliki tingkat kecerdasan emosional yang tinggi, maka akan memiliki tingkat kecenderungan burnout yang rendah. Khususnya bagi karyawan bagian pemasaran yang memiliki tuntutan untuk melakukan emotional labor setiap saat, sehingga membutuhkan kemampuan-kemampuan yang tercakup dalam kecerdasan emosional, agar terhindar dari emotional dissonance yang dapat mengarah pada kecenderungan burnout.

Berdasarkan uji korelasi Pearson Product Moment Correlation, didapatkan hasil bahwa masing-masing dimensi kecerdasan emosional memiliki hubungan yang signifikan dengan kecenderungan burnout. Namun, yang paling kuat hubungannya adalah dimensi self regulatory $(\mathrm{r}=$ -0.376; $\mathrm{p}<0.05)$. Masing-masing dimensi kecenderungan burnout juga memiliki hubungan yang signifikan dengan kecerdasan emosional. Namun, yang paling kuat hubungannya adalah dimensi reduced professional efficacy $(\mathrm{r}=-0.344 ; \mathrm{p}<0.05)$.

Hasil analisis tambahan terhadap kecenderungan burnout menunjukkan adanya perbedaan yang signifikan berdasarkan pendidikan terakhir $(F=3.101 ; p=0.049 ; p<0.05)$ dan posisi atau jabatan $(F=3.401 ; p=0.037 ; p<0.05)$. 


\section{Saran Teoretis}

Untuk penelitian selanjutnya, sebaiknya penelitian dilakukan pada subjek lain selain karyawan bagian pemasaran, seperti pada karyawan bagian lainnya. Sesuai dengan pendapat dari Muchinsky (2000) bahwa setiap orang dapat mengalami burnout apabila memang mengalami tekanan. Untuk memperdalam penelitian, dapat dilakukan uji analisis lebih lanjut mengenai keterkaitan dimensi antar variabel agar semakin terdapat konsistensi hasil penelitian. Selain itu, sesuai dengan keterbatasan penelitian ini, dapat juga dilakukan penelitian lebih lanjut mengenai data demografis pada masing-masing variabel.

\section{Saran Praktis}

Bagi perusahaan, mengingat adanya hubungan antara kecerdasan emosional dengan kecenderungan burnout, maka dapat dilakukan penyuluhan mengenai pentingnya kecerdasan emosional dalam bekerja dan juga mengadakan pelatihan untuk mengasah kecerdasan emosional karyawan. Perusahaan juga dapat melakukan tes untuk mengetahui tingkat kecenderungan burnout pada karyawan, dengan memperhatikan tingkat pendidikan dan posisi atau jabatan dari karyawan. Selain itu, usaha mengurangi kerentanan terhadap kecenderungan burnout juga dapat dilakukan dengan melalukan penyuluhan mengenai efek-efek negatif dari burnout, mengadakan sesi konseling bagi karyawan untuk berbicara kepada pihak penghubung dari perusahaan, dan juga dapat diadakan diskusi bersama antar karyawan agar sesama karyawan dapat berbagi cerita dan pengalaman.

Sebagai karyawan bagian pemasaran yang perlu mempraktekkan emotional labor setiap saat, kemampuan self regulatory dan self awareness sangat diperlukan. Oleh karena itu, sebaiknya para karyawan melakukan usaha-usaha untuk mengasah kemampuan self regulatory dan self awareness tersebut. Usaha ini dapat dilakukan dengan melatih kemampuan untuk merefleksi diri sendiri mengenai apa saja yang dirasakan agar dapat memahami emosi yang dirasakannya. Ketika seseorang telah memiliki pemahaman akan emosinya, maka usaha selanjutnya adalah melakukan penilaian terhadap emosi tersebut, sehingga dapat memilih emosi mana yang negatif dan mana yang positif. Hal ini sesuai dengan pendapat dari Gross dan Thompson (2006), yaitu seseorang mampu mengubah emosi negatifnya jika dilatih untuk melakukan penilaian emosi. Setelah memiliki penilaian emosi, maka seorang karyawan perlu melatih diri untuk menentukan respon terhadap emosi tersebut, agar responnya sesuai. 


\section{REFERENSI}

Akbar, S. N. (2013). Hubungan antara kecerdasan emosi dengan stres kerja pada perawat. Jurnal Ecopsy, $1(1), 38-42$.

Bakker, A. B., \& Heuven, E. (2006). Emotional dissonance, burnout, and in-role performance among nurses and police officers. International Journal of Stress Management, 13(4), 423-440.

Baumgardner, S. R., \& Crothers, M. K. (2010). Positive psychology. Upper Saddle River, New Jersey, NJ: Pearson Education.

Bergen, M., Dutta, S., \& Walker, J. O. C. (1992). Agency relationships in marketing: A review of the implications and applications of agency and related theories. Journal of Marketing, 56(3), 1-24.

Campbell, C., \& Rothman, S. (2005). A psychometric assessment of the maslach burnout inventory (general survey) in a customer-service environment. Management Dynamics, 14(2), 16-28.

Cordes, C. L., \& Dougherty, T. W. (1993). A review and an integration of research on job burnout. Academy of Management Review, 18(4), 621-656.

Corrigan, P. W., Holmes, E. P., \& Luchins, D. (1995). Burnout and collegial support in state psychiatric hospital staff. Journal of Clinical Psychology, 51, 703-710.

Ema, A. (2004). Peranan dimensi-dimensi birokrasi terhadap burnout pada perawat rumah sakit di Jakarta. Jurnal Psyche, 1(1), 33-46.

Goleman, D. (2005). Working with emotional intelligence: kecerdasan emosi untuk mencapai puncak prestasi. Jakarta: Gramedia.

Grandey, A. A. (2000). Emotion regulation in the workplace: A new way to conceptualize emotional labor. Journal of Occupational Health Psychology, 5(1), 59-100.

Gross, J. J., \& Thompson, R. A. (2006). Emotion regulation: Conceptual foundations. New York, NY: Guilford Press.

Khanifar, H., Maleki, H., Nazhari, K., \& Emami, M. (2012). The sudy of the relation between emotional intelligence and burnout of staff (Case study of staff at state universities in Ghom). Interdiscplinary Journal of Contemporary Research in Bussiness, 3(9), 564-582.

Lanawati, S. (1999). Hubungan antara emotional intelligence (EI) dengan intelegensi (IQ) dengan prestasi belajar siswa SMU Methodist di Jakarta (Tesis tidak dipublikasikan). Universitas Indonesia, Indonesia.

Lupiyoadi, R. (2001). Manajemen pemasaran jasa. Jakarta: Salemba Empat.

Marina, L., \& Sarwono, S. W. (2007). Kecerdasan emosional pada orang tua yang mendongeng dan tidak mendongeng. JPS, 13(2), 97-110.

Maslach, C. (1993). Professional burnout: Recent developments in theory and Research. London: Taylor \& Francis. 
Maslach, C., \& Jackson, S. E. (1986). Maslach burnout inventory manual (2nd ed.). Palo Alto, CA: Consulting Psychologists Press.

Maslach, C., Jackson, S. E., \& Leiter, M. P. (1996). Maslach burnout inventory manual (3rd ed.). Palo Alto, CA: Consulting Psychologists Press.

Muchinsky, P. (2000). Emotions in the workplace: The neglect of organizational behavior. Journal of Organizational Behavior, 21(7), 801-805.

Nikolaou, I, \& Tsaousis, I. (2002). Emotional intelligence in the workplace: Exploring its effects on occupational stress and organizational commitment. The International Journal of Organizational Analysis, 10(4), 327-342.

Poghosyan, L., Aiken, L. H., \& Sloane, D. M. (2009). Factor structure of the maslach burnout inventory: An analysis of data from large scale cross-sectional surveys of nurses from eight countries. Int $J$ Nurs Stud, 46(7), 894-902.

Santoso, S. (2010). Statistik multivariat. Jakarta: PT Gramedia.

Sevilla, C. G., Ochave, J. A., Punsalan, T. G., Regala, B. P., \& Uriarte, G. G. (1993). Pengaturan metode penelitian. Jakarta: UI Press.

Storbacka, K., Ryals, L., Iain, D., \& Nenonen, S. (2009). The changing role of sales: Viewing sales as a strategic, cross-functional process. European Journal of Marketing, 43(8), 890-906.

Sugiyono. (2010). Metode penelitian kuantitatif kualitatif dan $R \& D$. Bandung: Alfabeta.

Tawale, E. N., Budi, W., \& Nurcholis, G. (2011). Hubungan antara motivasi kerja perawat dengan kecenderungan mengalami burnout pada perawat di RSUD Serui-Papua. Jurnal Insan Media Psikologi, 13(2), 74-84.

Widiastuti, D. Z., \& Astuti, K. (2008). Hubungan antara kepribadian hardiness dengan burnout pada guru sekolah dasar. Jurnal Insight, 6(2), 142-154. 